\title{
The recent rock drawings of the Lenggong Valley, Perak, Malaysia
}

Mokhtar Saidin ${ }^{1} \&$ Paul S.C. Taçon ${ }^{2}$

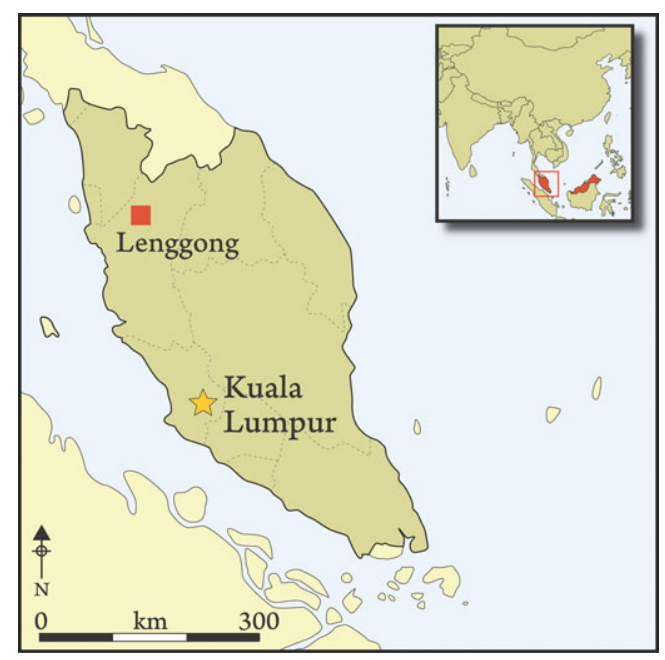

The authors present and interpret rock drawings found in caves in the Lenggong Valley, Perak, Malaysia. The drawings, which begin by depicting ritually important patterned mats, and continue with images of cars, bicycles and figures with their hands on their hips, provide rare and precious insights into how the indigenous people of the area came to terms with changes that occurred as the result of the arrival of Europeans in the late 1800s and early 1900s.

Keywords: Malaysia, Lenggong Valley, Gua Badak, rock art, drawings

\section{Introduction}

The rock art of East Asia is not well known and often overshadowed by research from Europe, southern Africa, Australia and the Americas. However, rock art has been consistently reported and studied in South, East and Southeast Asia since the late 1800s (e.g. for India see Cockburn 1899; Franke 1902; for Sri Lanka and Indonesia see Chen 2001). Rock art in Malaysia was reported as early as 1879 (Daly 1879; Price 2002: 239), around the same time that many significant sites in Spain and France, such as Altamira and Chabot, were being discovered (Bahn \& Vertut 1997: 14-22). Charcoal drawings were found in three large caves of the Sungei Batu complex near Kuala Lumpur, with excavations uncovering stone tools and ceramics. Unfortunately, the drawings were badly vandalised before they could be recorded (Chen 2001: 767).

1 Centre for Global Archaeological Research, Universiti Sains Malaysia, 11800 USM, Penang, Malaysia (Email: mmokh@usm.my)

2 School of Humanities, Gold Coast campus, Griffith University, Queensland 4222, Australia (Email: p.tacon@griffith.edu.au) 
Table 1. Known sites with surviving rock art from peninsular Malaysia.

\begin{tabular}{lll}
\hline State & \multicolumn{1}{c}{ Cave (Gua) } & Location \\
\hline Perak & Gua Badak & Lenggong \\
& Gua Dayak & Lenngong \\
& Gua Gelok & Lenggong \\
& Gua Batu Puteh & Lenggong \\
& Gua Batu Tukang & Lenggong \\
& Gua Kelilawar & Sg. Siput \\
& Gua Tambun & Ipoh \\
Kedah & Gua Batu Putih & Kodiang \\
& Gua Cerita & Langkawi \\
Pahang & Gua Kecil & Raub \\
& Gua Batu Luas & Kuala Keniam \\
Kelantan & Gua Batu Cincin & Ulu Kelantan \\
& Gua Kambing & Ulu Kelantan \\
& Gua Chawas & Ulu Kelantan \\
& Gua Tagut & Ulu Kelantan \\
\hline
\end{tabular}

About 50 years later, a preliminary study of another cave with charcoal drawings was published by Evans (1927b). He photographed and briefly described Gua Badak, a small limestone cave in the Lenggong Valley, Perak. Further research was undertaken in the late 1950s with the discovery of Gua Tambun at Ipoh (Matthews 1959, 1960; Knuth 1962) but by 1990 there were still only four sites known from peninsular Malaysia (Adi 1990: 92). There are now 15 known rock art sites from across this region (see Table 1 and Zulkifli 2003 for brief details of some), not including megaliths inscribed with symbols in the south. There are also a number of sites in Sabah (e.g. Bellwood 1988; Gansser 1990) and Sarawak (e.g. Datan 1993), and new discoveries continue to be made (e.g. Mokhtar et al. 2008). Despite this, only brief Malaysia-wide summaries of the rock art have been produced (Datan 1998a \& b; Adi 2007; Mokhtar 2008) and only two detailed studies published (Datan 1993; Tan \& Chia 2010).

In 2007, a new Malaysian rock art research programme was initiated. One of its goals is to locate and document previously unknown sites and in this regard there are many areas of high potential requiring survey. Work began with surveying for unrecorded sites in part of Sabah (Mokhtar et al. 2008), the first comprehensive recording of Gua Tambun (Tan 2010; Tan \& Chia 2010) and the mapping of sites in the Lenggong Valley of Perak, in the northern Malaysian Peninsula. We report on the latter, placing this art in historic, archaeological and ethnographic contexts before interpreting it in relation to changes brought about by the arrival of Europeans.

\section{Lenggong Valley rock art sites}

The Lenggong Valley archaeological area (Figure 1) is located in the state of Perak about $90 \mathrm{~km}$ north of Ipoh. The Banjaran Bintang limestone range bounds its western side while 


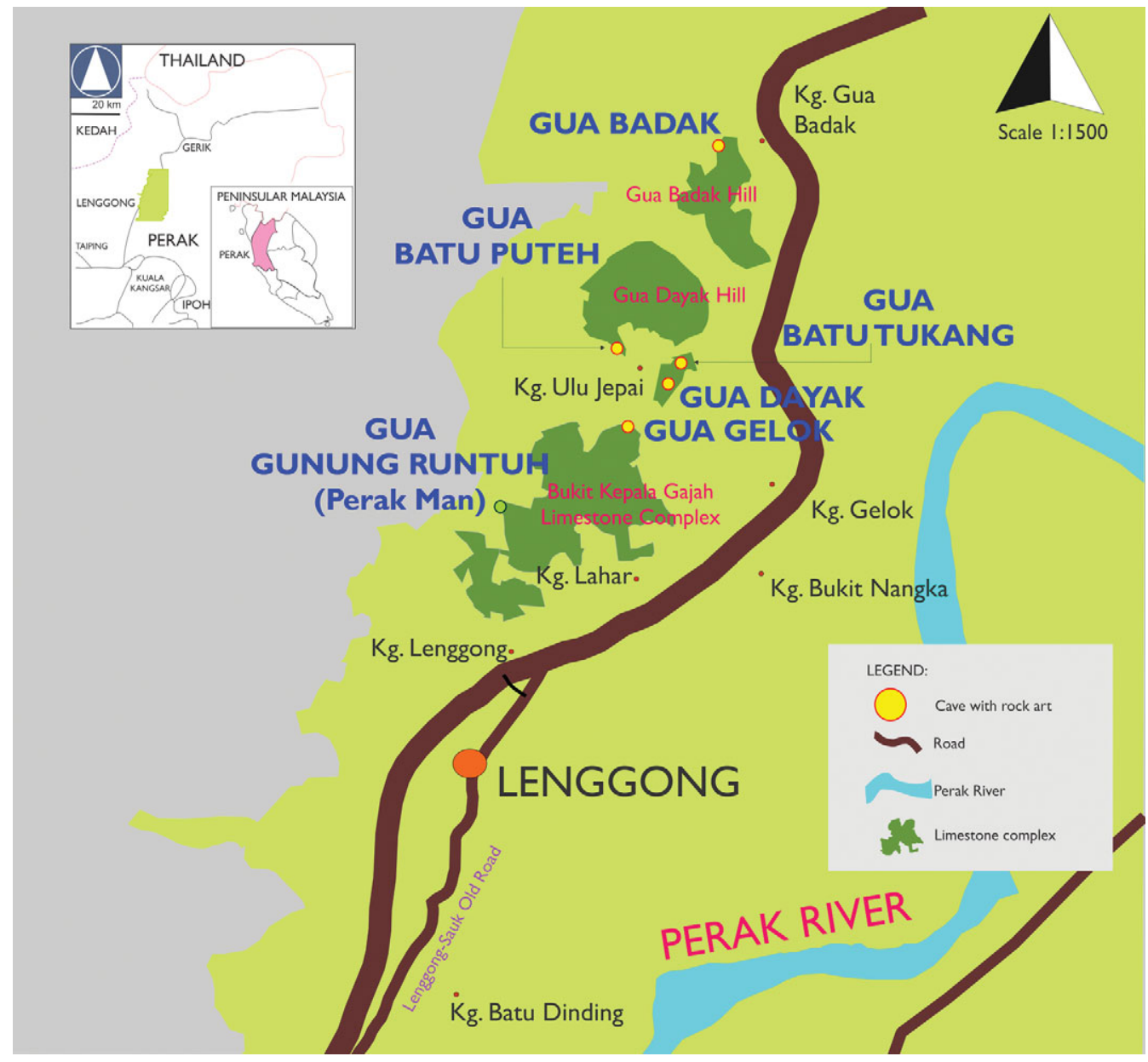

Figure 1. Map of the Lenggong archaeological area with rock drawing sites indicated.

the massive Banjaran Titiwangsa lies to the east. It runs roughly north-south with the Perak River flowing swiftly through the centre of the valley floor. It is part of the traditional rainforest home of the Semang, often referred to as Negritos in early literature (Skeat \& Blagden 1906; Schebesta 1928; Evans 1937). Genetic studies suggest Semang Negritos have been in northern Malaysia for at least 50000 years, possibly associated with an expansion of modern humans out of Africa (Hill et al. 2006).

This is an area of high rainfall, a warm to hot humid environment and, traditionally, thick jungle. There are 72 limestone gua (caves/shelters) in the now light- to medium-forested Lenggong area. All 72 have been documented but only 5 have rock art, consisting of about 400 surviving charcoal drawings: Gua Badak, Gua Dayak, Gua Gelok, Gua Batu Puteh and Gua Batu Tukang (Figure 1). Evans (1918) states there were drawings in a sixth cave, Gua Kajang, but they have not survived. All of the rock art sites are located low in the landscape, close to the valley floor and river, in contrast to early Neolithic and Palaeolithic sites, such 


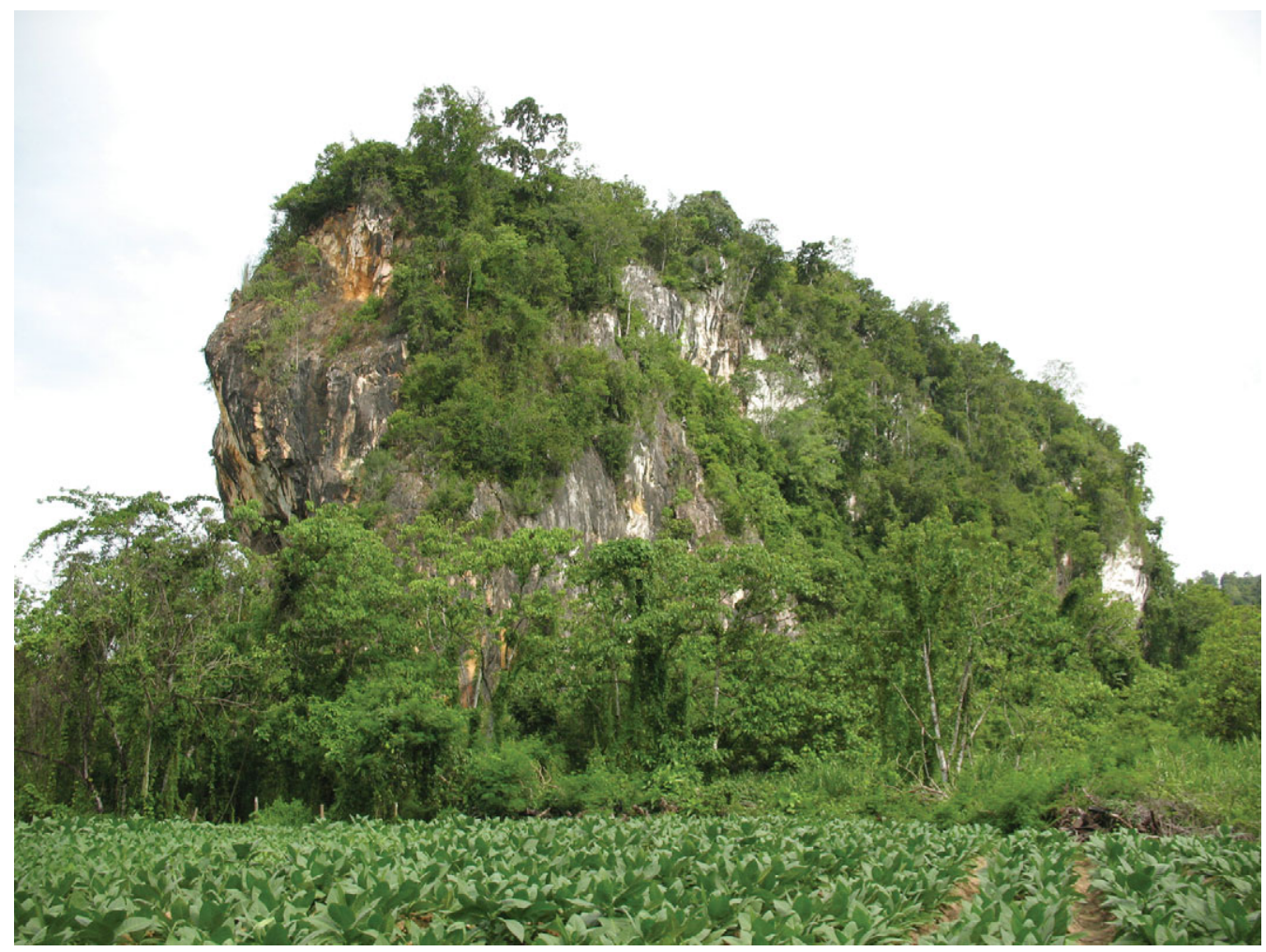

Figure 2. The limestone outcrop ('pillar') containing Gua Badak as it is today.

as Gua Gunung Runtuh where the Perak Man burial was uncovered, which are at varying altitudes. The art sites are also more precisely described as rockshelters or shallow caves, which is consistent with early observations that the Semang do not usually frequent deep caves, preferring rockshelters (Wray 1897; Skeat \& Blagden 1906: 2, 168). The Semang also lived in various types of huts (Skeat \& Blagden 1906; Schebesta 1928; Evans 1937; Williams-Hunt 1952a).

Gua Badak (Figures $2 \& 3$ ) is the best known rock art site, first described by Evans (1927b) and Schebesta (1928: 47, 163). Both reported not only charcoal drawing but also white pictures 'produced by scratching away the surface of the limestone rock in places where it has become discoloured' (Evans 1927b: 105). Unfortunately, green algae and weathering has obliterated the white rock art despite the pictures being quite clear in Evans' photographs (1927b: pls. 30-32). According to Schebesta (1928: 163) there once was a cave called Gua Paiong immediately above Gua Badak.

Faulstich (1991) studied Gua Badak in the 1980s and in 1991 reported that the entire site had been destroyed by quarrying. Fortunately, only the upper cave was destroyed by the mining, which ceased in 1987, and much of Gua Badak has survived, despite much rock fall and boulders now partially covering two panels. These heaped boulders are part of Gua Paiong, the original upper cave. 


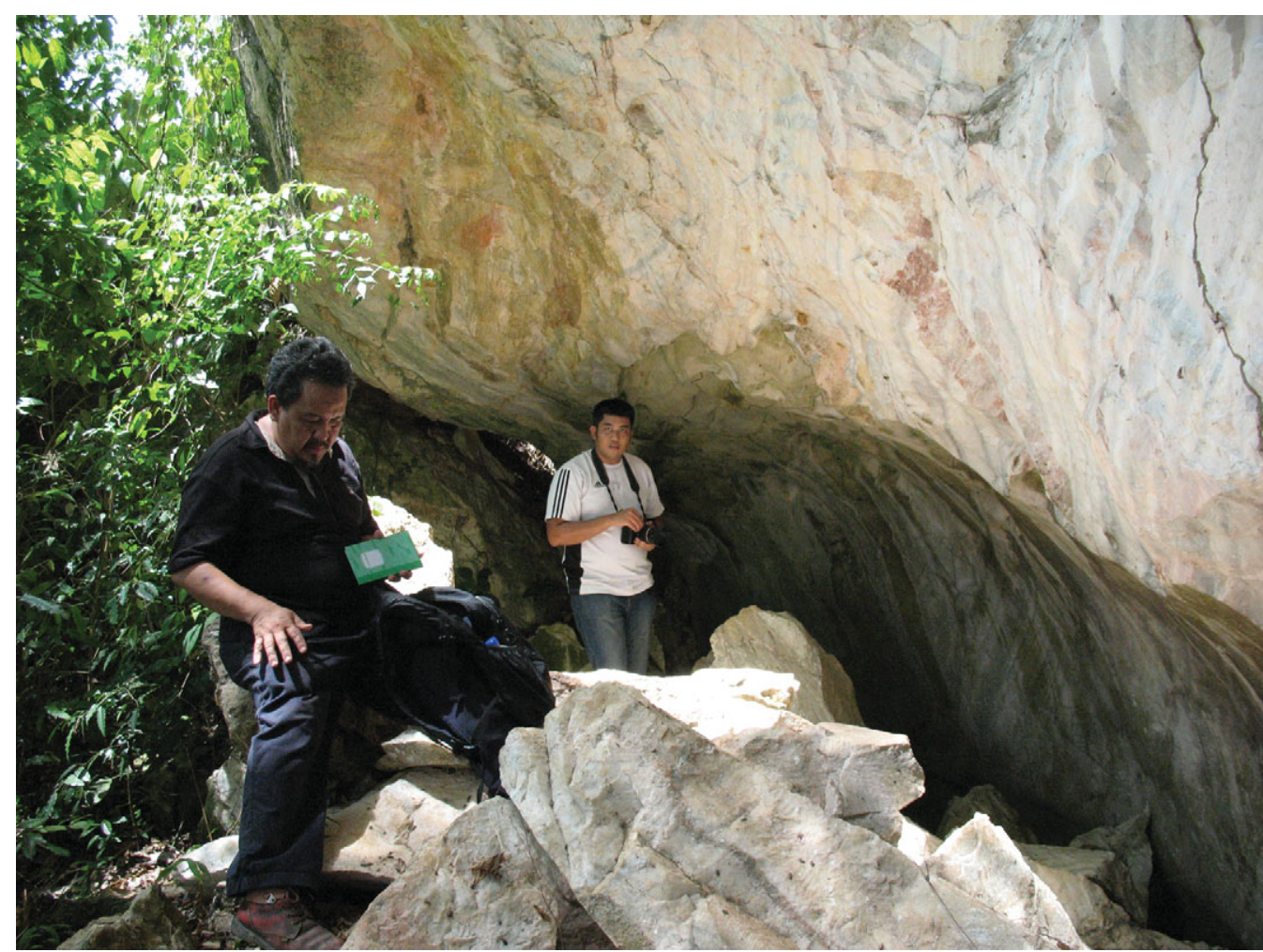

Figure 3. Mokhtar Saidin and Noel Hidalgo Tan on collapsed boulders at the front of Gua Badak.

Today Gua Badak measures $13.2 \mathrm{~m}$ wide by $14.1 \mathrm{~m}$ deep and reaches a maximum height from the original ground level at the back of the shelter of $4.1 \mathrm{~m}$. At the open front, where the upper cave once was, the drip line is at a height of about $10 \mathrm{~m}$. The shelter faces northwest at $42^{\circ}$. We recorded 136 charcoal drawings consisting of various types of geometric and figurative art. Nine of the large geometric designs appear to be depictions of mats (Figure 4) and a basket. Seven mats and the basket are clustered together in a panel on the left; one mat was depicted on the main right-hand panel. Various human figures, animals, some plants such as coconut palms, vehicles and a Malay style house (Figure 5) still survive in various places but there are fewer charcoal drawings than when Evans visited. Notable subjects include a man leading a horse, human figures on horseback, a human riding an elephant, hunting scenes, seven motor cars, two bicycles, a motorcycle (Figure 6), an early 1900s horse-drawn buggy (Figure 7) and a rickshaw. Almost 60 per cent of the drawings are human figures and many have one or both hands on their hips, including one with a gun, some riding horses and one leading a horse. Transport (via horses, elephants, motor vehicles, bicycles and rickshaw) is a common theme but there is an interesting mix of traditional and introduced subject matter in the figurative art.

Figurative drawings were placed right across the shelter while most of the mats and other geometric designs were confined to the left side. The mat drawings appear older than the figurative art; in one instance figures lie over the edge of a mat. Mats are lighter in colour 


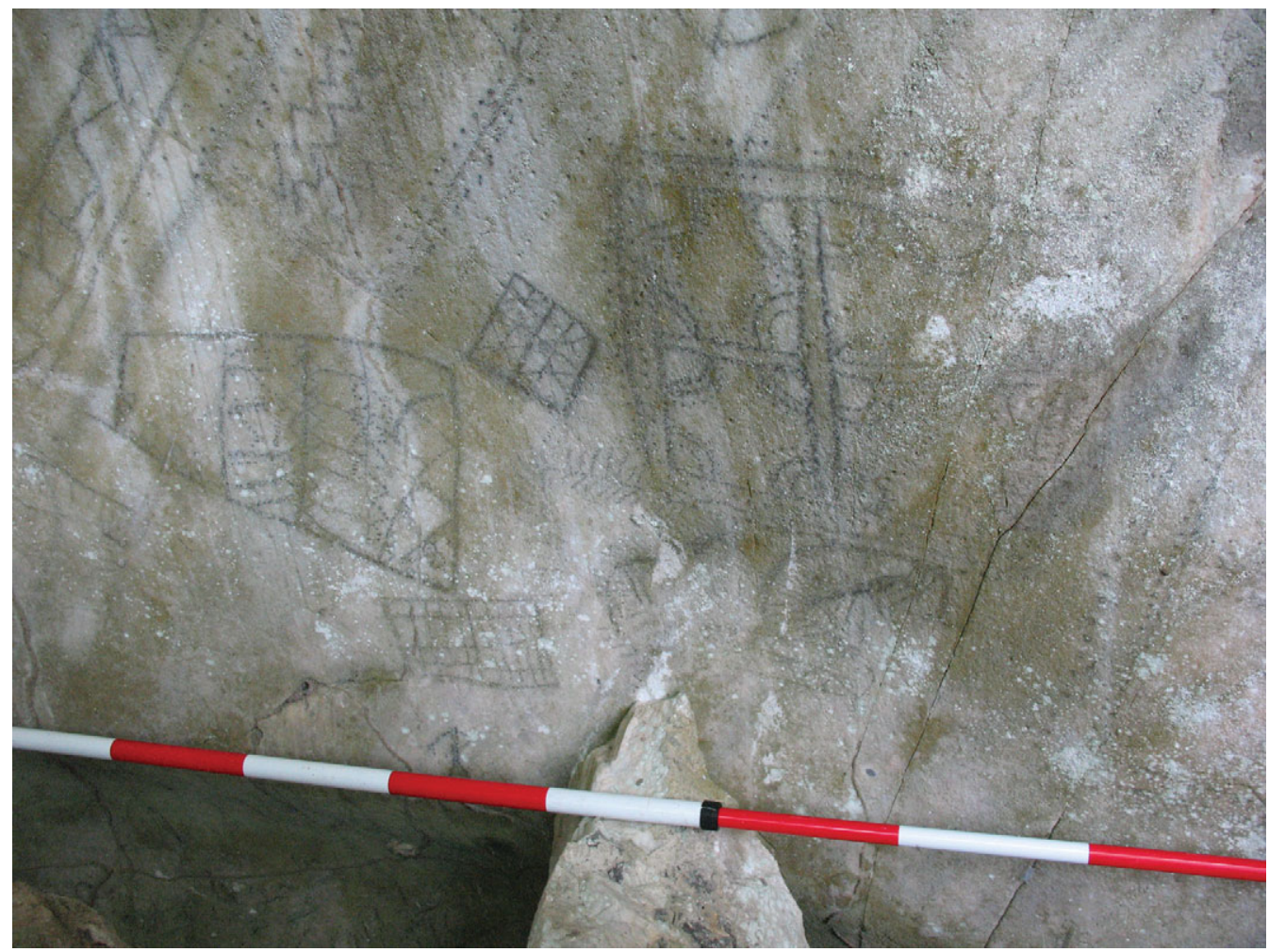

Figure 4. Gua Badak mat designs.

than figures, larger and were depicted using different stylistic conventions. They exhibit more fine workmanship than the figures and invariably were placed in relation to natural hollows, pitting, cracks and other features of the limestone surface. In some cases, edges or infilled designs consisting of rows of charcoal dots mimic nearby natural rows of pits on the wall. It is almost as if the wall itself suggested what to depict and design elements to be used. The figurative art does not exhibit such a relationship.

Finally, there are two large boulders with engravings consisting of artificially enhanced natural rows of pits, in one case with an additional line at an oblique angle. The boulders are from the collapsed upper cave, which may once have had a number of such engravings. Like the mats, these illustrate direct engagement with the rock surface. Recent scratched graffito has damaged some of the drawings.

Gua Dayak has 152 surviving charcoal drawings but here geometric designs account for about 59 per cent of the art rather than human figures as at Gua Badak. One of us (MS) observed Semang still living in this limestone cave in 1987. The drawings are found on several connected wall and domed ceiling panels in an oval raised bay on the left near the front, the uppermost chamber. Many of the geometric designs have design elements found in the old mat drawings of Gua Badak in isolation or in small mat-like depictions. Some of the rows of dots and other geometric designs are aligned with natural cracks or rows of natural pits in the limestone ceiling, as with Gua Badak mats. Notable images include two 


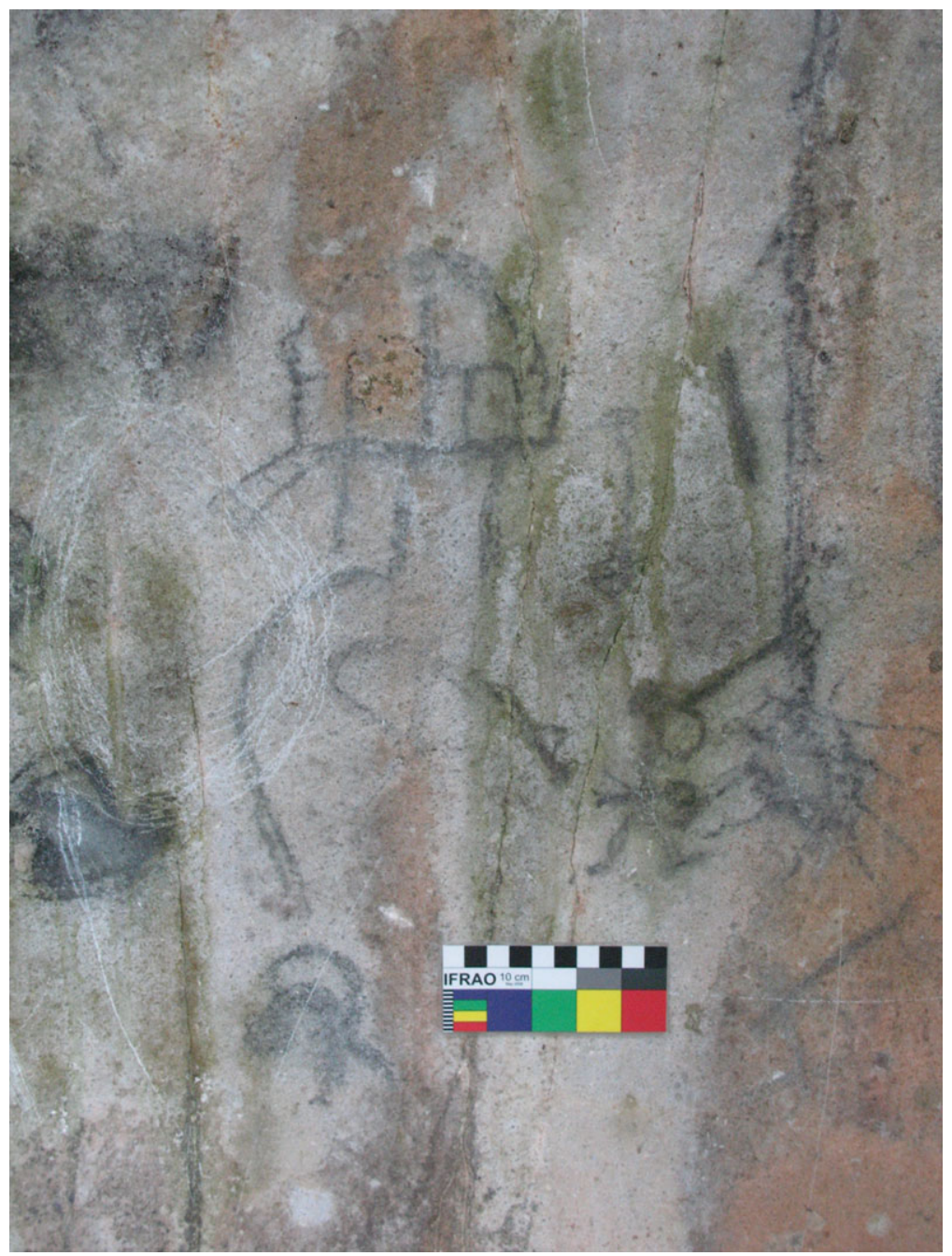

Figure 5. A Malay style house with a ladder, Gua Badak.

human figures using a traditional domed fishing net with bamboo supports, two human figures with bags on their backs, a motor car, what appears to be an elephant pulling a wheeled cart (see Evans 1918: 228) and a 1960/70s classic peace symbol, which may be associated with one of the most recent drawing episodes.

A fascinating composition (Figure 8) consists of a human figure with a kris (Malay knife) tied to its waist and a sword-like object with the handle in one hand and the other arm straight out from the body. Below is a figure holding a 'rifle' in one hand, the other resting on its hip.

Gua Gelok is also a limestone cave. There are 38 charcoal drawings concentrated in one section, an upper bay at the front left. Geometric designs account for 53 per cent of the art while human figures make up 26 per cent. Important depictions include a human figure on a horse with hands on hips (Figure 9) and another with hands on hips above a 


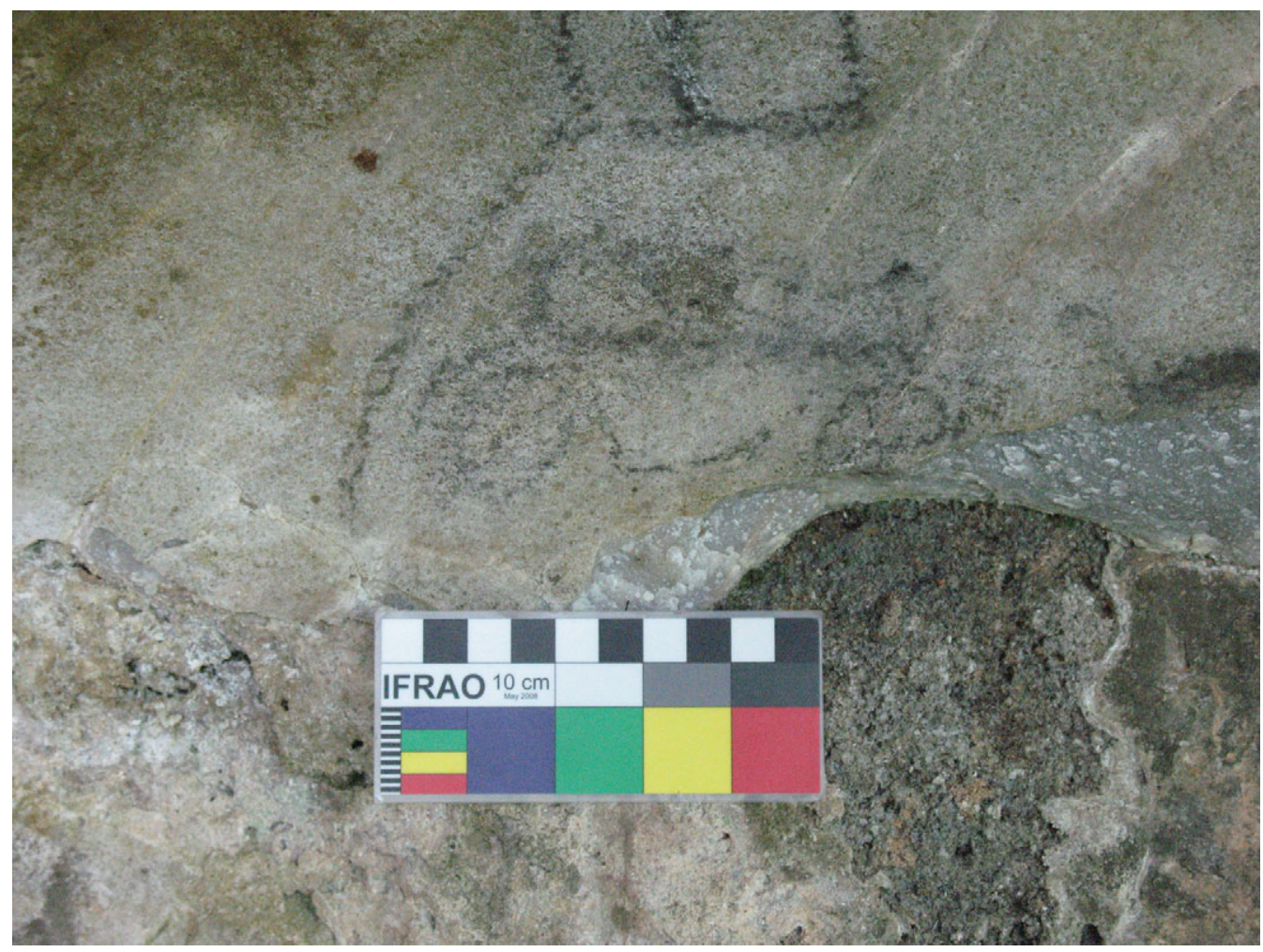

Figure 6. A rare depiction of a motorcycle at Gua Badak.

bicycle (Figure 10). There are also standing figures with hands on hips and others with arms extending out from their bodies.

Gua Batu Putah is a large open shelter with 53 charcoal drawings spread across its length in small groupings. Most are geometric (53 per cent) or human-like (40 per cent). Notable subjects include a small river boat and a bridge-like design. The latter has three human figures around it, two below and one above. All have hands on hips. There are other human figures with hands on hips in the shelter and a depiction of a bicycle.

Gua Batu Tukang is a long, open rockshelter with all of the charcoal drawings clustered at the far northern end. There are 15 geometric designs and 3 animal-like figures. All have a very rough, hurried appearance exhibiting less skill than drawings at the other four sites. Most geometrics are ovals with line infill that were purposely placed in natural hollows.

\section{Historic, archaeological and ethnographic contexts}

\section{Historic}

Malays first travelled up the Perak river in the sixteenth century (Maxwell 1881: 89) while the Portuguese were the first Europeans to arrive where the river meets the coast, in 1613 (Macgregor 1955). This was followed by the Dutch in 1746-47 but they did not penetrate far up the river either (see Maxwell 1881 and Dutch Governor Wilhem Albinus's report in 


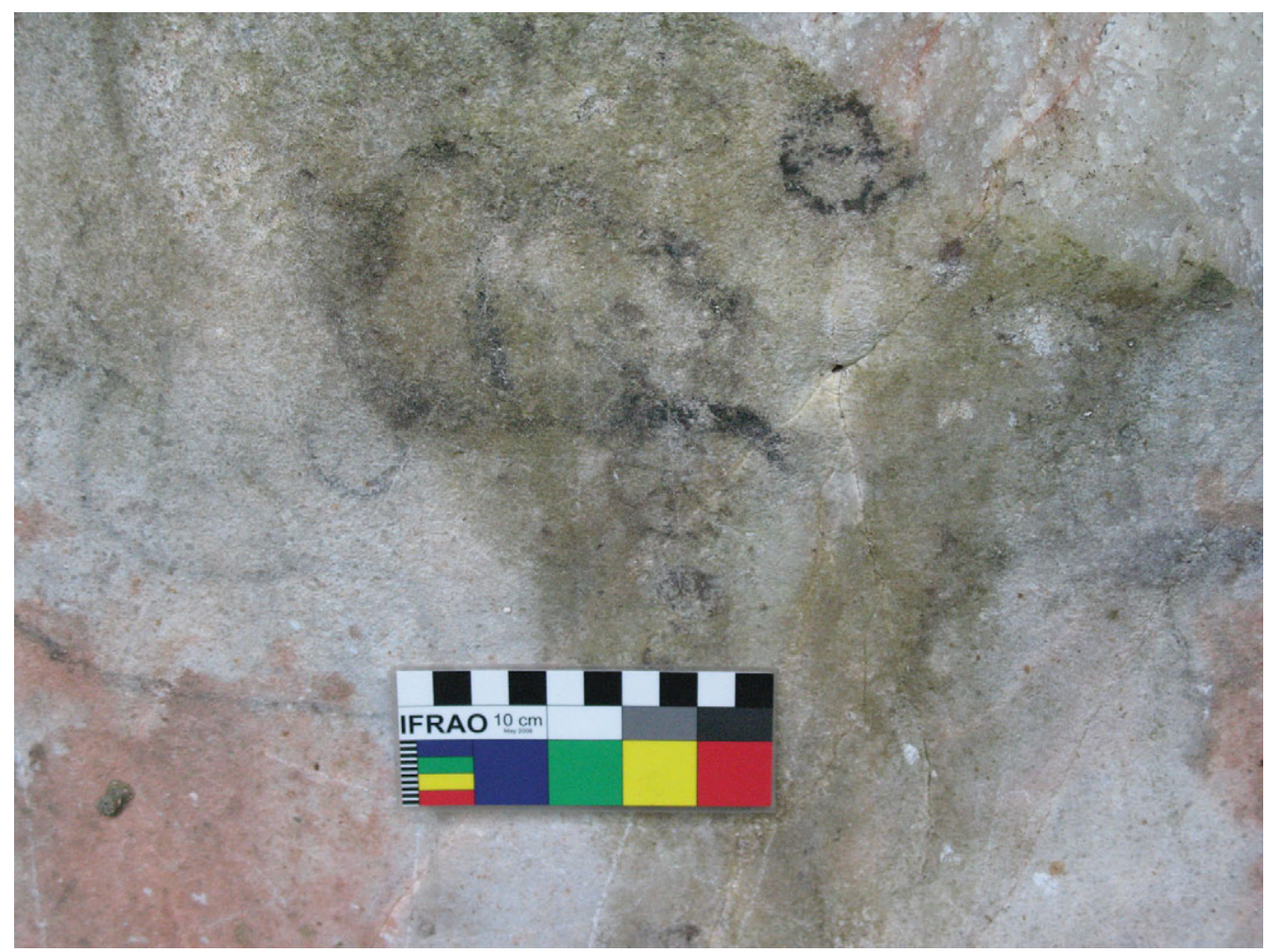

Figure 7. A charcoal drawing of a horse-drawn buggy, Gua Badak.

Bastin \& Winks 1966: 102-106). The British established a colony on the island of Penang in 1786 (e.g. Clodd 1948). A treaty was made with Perak in 1826 (Bastin \& Winks 1966: 138) but permanent British intervention began in 1874 (Bastin \& Winks 1966: 141).

The British arrived in the Ipoh-Lenggong area in late 1800s. In 1886 the exploration and excavation of caves in Perak began near Ipoh (e.g. see Wray 1897; Evans 1918: 227), followed by Lenggong in 1917 (Evans 1918). The British put a road into the area from Taiping and Kuala Kangsar toward the end of World War I (Schebesta 1928: 18). When Schebesta visited a Lenggong site in 1924 he 'asked a boy to make some charcoal drawings', satisfying him that 'most of the pictures in the cave were Semang work'(1928: 48). I.H.N. Evans (1918, 1922a \& b, 1923, 1927a \& b, 1937) spent much time working with and studying the Lenggong Semang, arriving in 1917 and continuing throughout the 1920s. During World War II Major Williams-Hunt took great interest in the Semang and observed rock drawings being made in 1950 (1952a: opp. 79). At one site a 'Lanoh Negrito' drew a portrait of his head that he claimed was 'an excellent likeness' (1952a: 5; see sketch). Unfortunately, this drawing was not located during our research and may not have survived.

\section{Archaeological}

In many ways the Lenggong Valley is the cultural centre of prehistoric development in peninsular Malaysia (Goh \& Mokhtar 2009: 71). For instance, it has long been known 


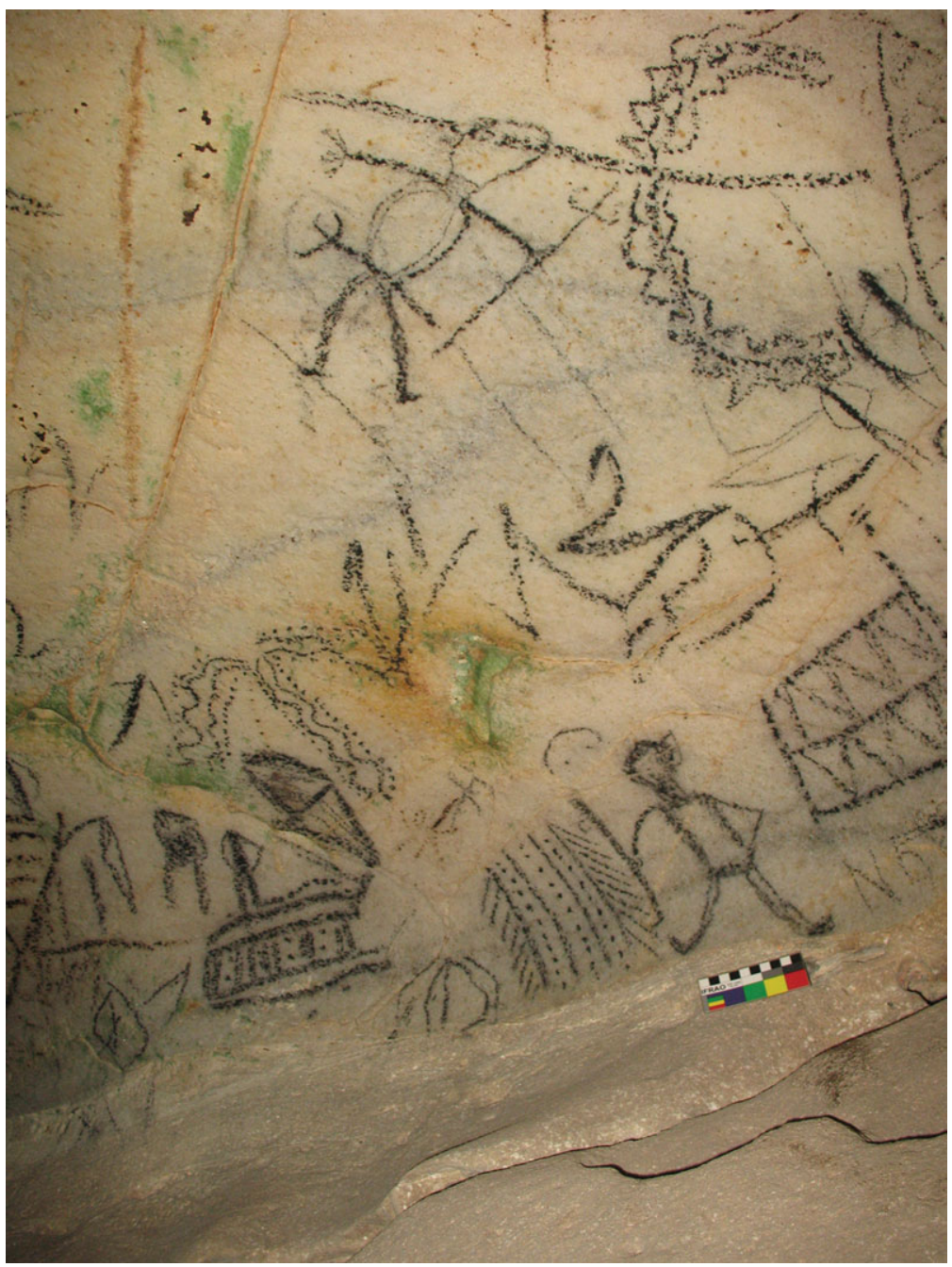

Figure 8. Two human figures from Gua Dayak: one has a kris around the waist and a sword in one hand; the other is holding a rifle in one hand while the other hand rests on the hip.

for a wide range of Palaeolitic and Neolithic sites, such as Bukit Jawa that has stone tools 100 000-200 000 years of age, the Palaeolithic site of Kota Tampan with layers dated to between 75000 and 30000 years ago, peninsular Malaysia's oldest burial, Perak Man, dated to between 10000 and $11000 \mathrm{BP}$ and a wide range of Neolithic sites including limestone caves with elaborate burials (Zuraina 1994, 2003; Goh \& Mokhtar 2009; Hamid 2009). Excavations in the late 1980s and early 1990s revealed that many of the rock art sites were first occupied between about 4000 and 8000 years ago (Chia 1997; Zuraina 2003).

Gua Badak was first excavated by Evans and Callenfels in October 1926 (Evans 1927a: 101; Evans \& Callenfels 1928) and Williams-Hunt in 1950 (Williams-Hunt 1951, 1952b). Evans and Callenfels found Semang people living in the shelter when they arrived to 


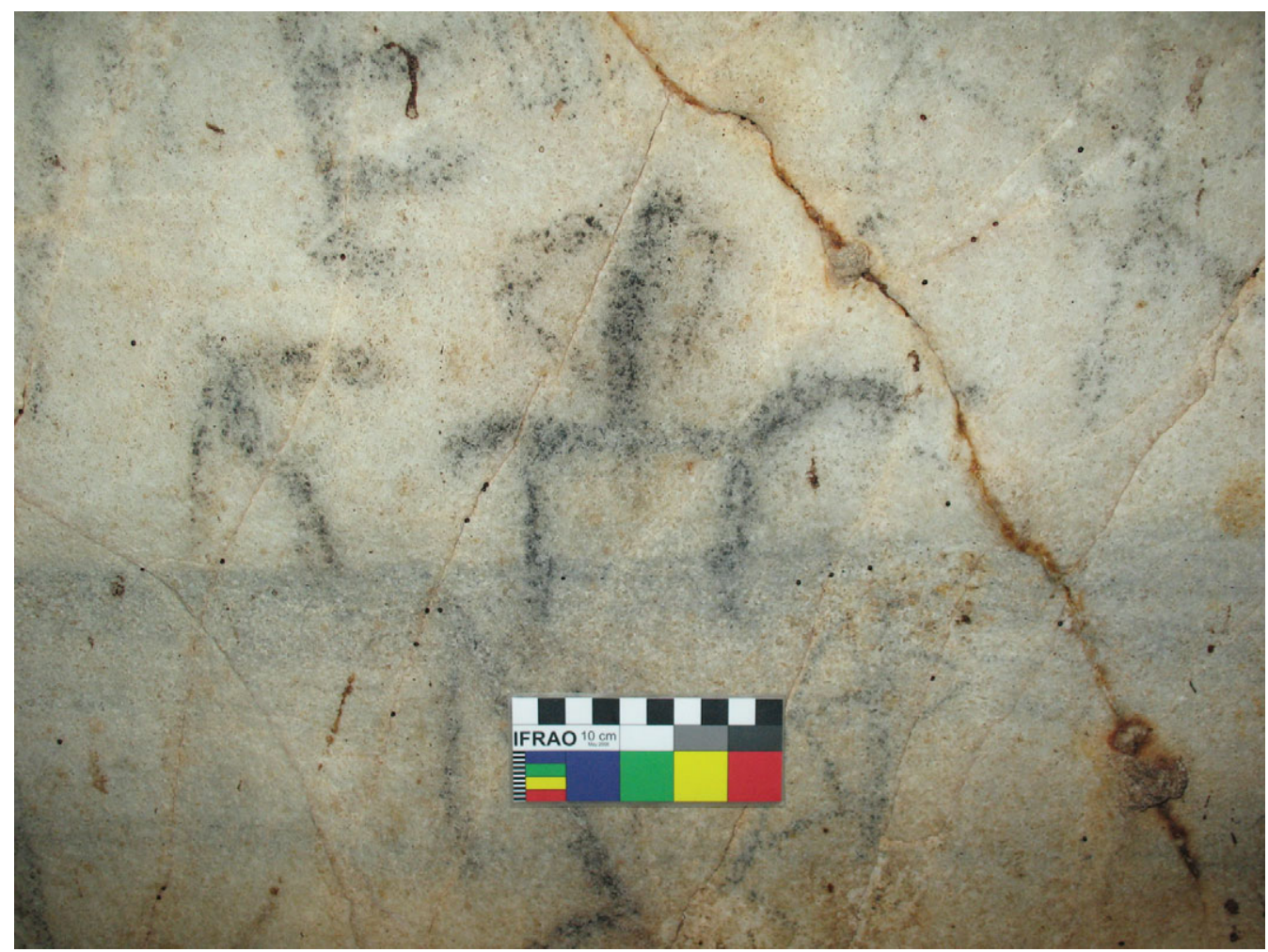

Figure 9. A human figure on horseback with hands on hips, Gua Gelok.

excavate. They had been there for about six days and most of the men were persuaded to assist the excavation (Evans 1927a: 101). Both Evans and Williams-Hunt's excavations revealed stone tools, flakes, cord-marked pottery and other material (Evans \& Callenfels 1928; Williams-Hunt 1951, 1952b) similar to that of other caves of the area excavated since 1987.

Williams-Hunt $(1951,1952 \mathrm{~b})$ also excavated Gua Batu Tukang and Gua Gelok, where two almost complete bowls were recovered (1951: 190). Chia (1997: 43) excavated Gua Badak in 1991 but found only four sherds at the $0.2 \mathrm{~m}$ level and no dateable material. Sherds at Gua Dayak have been dated to about 1500 years ago and at Gua Batu Tukang to about 4000 BP.

While excavating at Gua Badak, Evans looked for old rock art but did not find any despite some extensive searching, as it 'seems probable that old drawings would not persist, as the cave walls appear to powder somewhat under the influence of the atmosphere' (1937: 126). The nearest old rock art, consisting of ochre (haematite) paintings, is at Gua Tambon, Ipoh, about $90 \mathrm{~km}$ south. But the Lenggong rock drawings are very different to the Gua Tambon rock paintings as Tan and Chia (2010:17) note, despite Gua Tambon also being traditionally associated with the Semang. 


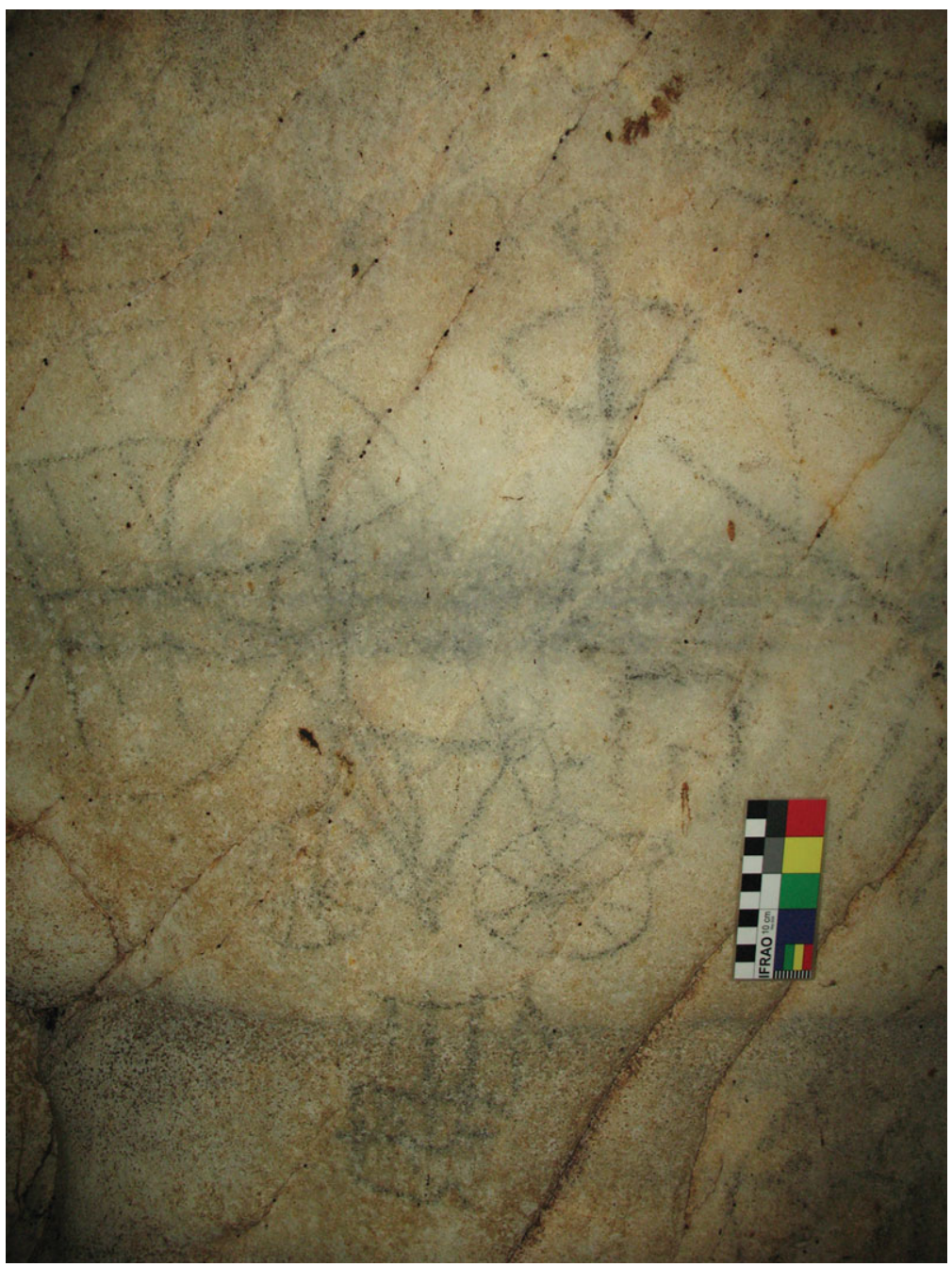

Figure 10. A human figure with hands on hips above a bicycle, Gua Gelok.

\section{Ethnographic}

On three occasions Evans observed Negrito people living at Gua Badak (1927b: 105). They told him about many aspects of their beliefs and traditional way of life (1923, 1927a), including that the mats depicted at the site are meant to represent the mats of some of the ancestor deities' (1927b: 106). An important story told to Evans (1927a) by Gua Badak Negritos throws further light on their significance in relation to the origin of the Perak river, nearby landforms and the indigenous people themselves. It involves Yak Ku-ung, the first woman and first ancestor of the Negrito people (1927a: 101).

'Yak Ku-ung lived at sunrise, where the Perak river had its source. There was a dragon at the source of the river, which then flowed past the Gua Badak through the Gua Kajang and entered the sea at Tasek, where the sun then fell. Yak Ku-ung told her grandsons, 
one of whom was named I-ok, to work seven days, seven seasons, seven years, and cut the dragon in two. This they did. Now the dragon at the source of the river bore the Batu 'Rem on its back and when they cut through the dragon the sea retreated, the river changed its course, the earth melted, and the grandsons were carried away by the water. At last, after the seven days, the seven seasons, the seven years, the water retreated and the grandsons came to rest and returned to their grandmother. After that the country became as it now is and Yak Tanggoi and others appeared on the earth'(1927a: 103).

The Batu 'Rem is a pillar that supports the upper world and appears frequently in Negrito stories (1927a: 104). One of the ancestors later became pregnant and gave birth to a son. This man had a dream about his father that was to lead to the Lenggong area becoming populated with people. His father said:

$\therefore$... that if he wished the country to become populous his mother must make seven mats. So his mother made headdresses (mènulang) of chingchong fibre and the mats, and hung them above the place where her son slept. Then his father came at night and took the mats and headdresses and told his son that he must marry his mother. And that is the way the country became populous' (1927a: 103-104).

Semang mat-making by women was first described by Skeat and Blagden (1906: 382-87), 'the chief articles thus made being the mat-work bags or sacks and the wallets which are used by the Semang for holding their husked rice, roots, and fruits, and similar articles'.

Schebesta (1928: 163) adds further light on the significance of limestone caves for the Semang, especially Gua Badak. Here he found 'offering bowls for the souls of the dead'. In the original upper cave (destroyed in the 1980s) he noted the Semang wipe their hands over the damp limestone wall and smear the forehead with the water dripping down it' (1928: 163). Apparently this custom was common among the Semang everywhere and 'This limestone rock is certainly treated with general reverence among all Semang tribes...' (1928: 163). Schebesta states that it is called Batu Ribn, the abode of various supernatural beings'. Here he is referring to the sacred limestone pillar that supports the heavens and he thought that the limestone hill containing Gua Badak (Figure 2) was the pillar. However, Evans (1927a: 104) places it to the north, in Kedah state. It is probable that a number of limestone hills were considered pillars supporting the heavens for the Semang.

Development of the Lenggong region since the 1950s has 'forced the Semang deeper into the jungles in the northern part of Perak and the neighboring state of Kelantan, where they continue to lead a nomadic hunter-gatherer lifestyle that frequently brings them back and forth between the Thai-Malaysian border' (Tan \& Chia 2010: 17).

\section{Interpreting the rock art}

A formal analysis of the drawings, and their landscape, historic, archaeological and ethnographic contexts, has led to the following conclusions. First of all, Gua Badak and Gua Dayak were the main centres of rock art activity in the Lenggong Valley, although it is highly likely that there are other undocumented sites, including some with much older rock art, elsewhere in Perak and nearby parts of the Malaysian Peninsula. At Gua Badak 
there were at least two major drawing phases. The first consisted of making mat, basket and related geometric designs. These traditional designs probably related to the ancestral story about the creation of the Perak River and the Semang people, summarised above, especially as seven large mats were depicted in one location. They likely predate the arrival of the British in the area and at that time Gua Badak, and the now lost cave above, may have been considered a sacred focal part of the landscape.

With the arrival of the British and increasing numbers of Malay, new roads near Gua Badak and the many changes these brought to the Semang way of life, there appears to have been an impetus to record both varied traditional pursuits and the new people, animals and objects entering the area. For some reason, transport became a major theme, with many depictions of horses, motor vehicles, bicycles and so forth. There was also a related fascination with elephants involved with transport, a human figure shown riding an elephant at Gua Badak and an elephant pulling a wheeled cart at Gua Dayak. Nasir (1977: 45) has suggested that drawings of a man on horseback at Gua Badak may be depictions of Hubert Berkeley, the District Judge of Hulu Perak in 1889:

\section{'Berkeley was regarded as a very important person by Negritos. When he travelled to the Malay villages he normally rode a horse, and the route that he followed to the village of Lenggong took him directly past Gua Badak' (Faulstich 1991: 24-25).}

Transport is a major theme in contact rock art worldwide, resulting in engraved, painted and drawn ships, horses, camels, bicycles, animal-drawn carts, buggies and even aeroplanes at many sites, especially in Australia (e.g. see May et al. 2010; the Djulirri site has a painting of a buggy similar to the one at Gua Badak). The Semang were no different - they were fascinated by the things that brought newcomers to their land as much as the newcomers themselves. Perhaps drawing these things helped them come to terms with change, explain it to others or record it for posterity.

The human figures with their hands on their hips are particularly interesting, since many may be depictions of the British. In many parts of southern Africa, North America and Australia human figures with hands on hips were said to be depictions of Europeans by indigenous elders or have been interpreted as such by archaeologists because of their association with introduced subject matter. Perhaps indigenous peoples were fascinated with hands that disappeared into pockets, or they were emphasising an arrogant stance that dominant Europeans often took, or this stance was common among Europeans but not in their own societies. For instance, the Semang to this day still do not use such a stance.

Whatever the motivation, it appears to have become a common shorthand convention among many widely separated indigenous hunter-gatherers for distinguishing a depiction of a European from that of a person from another culture (see Figure 11). Among the Semang drawings many of these 'hands-on-hips' figures ride horses or lead a horse with one hand while the other hand rests on the hip. This hypothesis is further supported by the Gua Gelok human figure with hands on hips above a bicycle (Figure 10) and the Gua Dayak drawing of a human figure with kris, sword and outstretched arms (presumably a Malay man) versus a nearby human figure holding a rifle in one hand while the other is on its hip (Figure 8). 


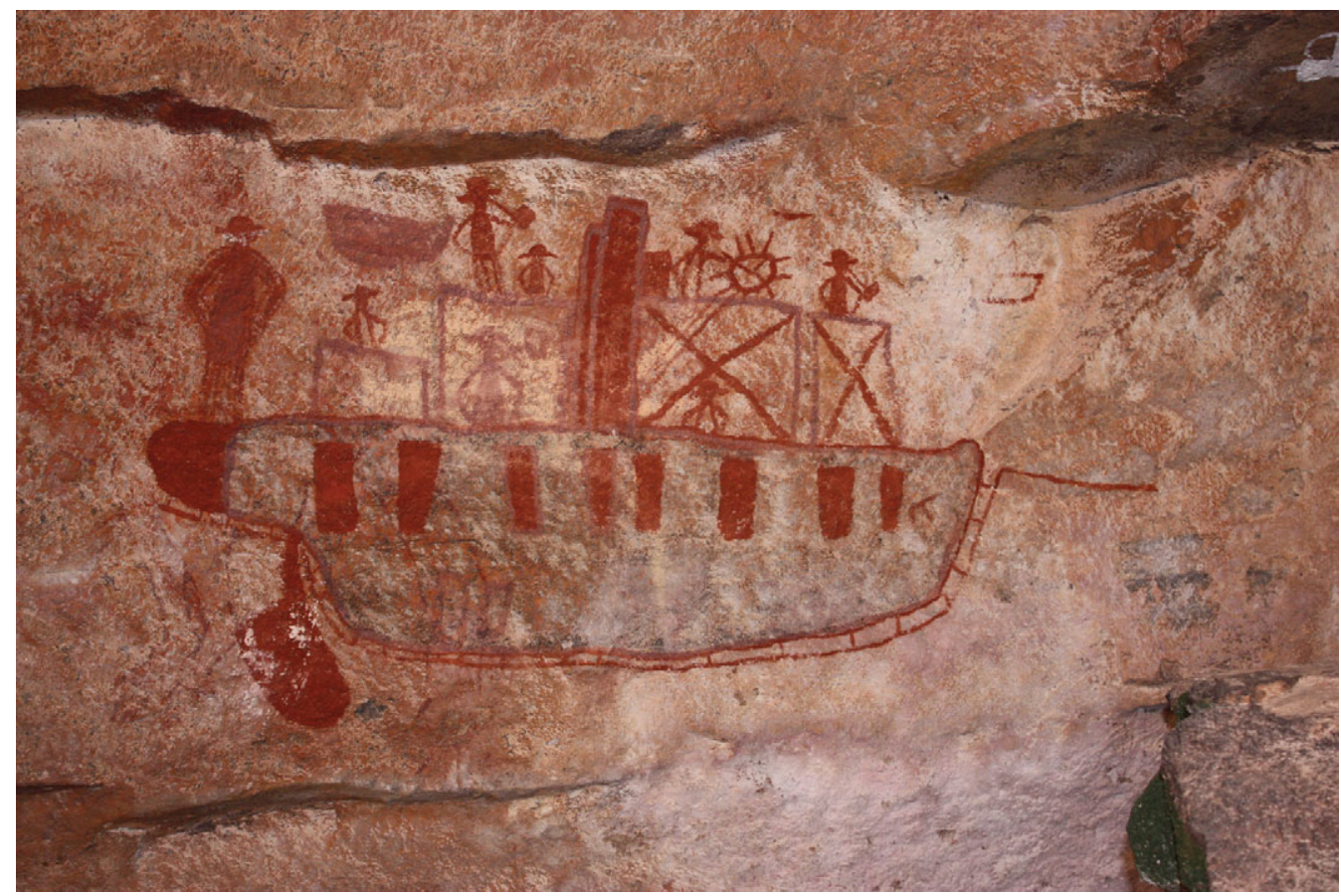

Figure 11. A steamship painted in the early 1900s at Djulirri, Arnhem Land, Australia. Note that the European crew is shown with their hands on their hips and smoking pipes.

Other figures at the sites engaged in typical Malay or Semang activities are not shown with hands on hips, except for one Gua Badak figure interpreted as hunting with a blowpipe that has one hand on a hip.

When Evans, Schebesta and others arrived at Gua Badak the charcoal figurative drawings and scratched white pictures were likely between 40 and only a few years old. Much of their subject matter appears to have been inspired by changes that occurred as the result of a road forced through the jungle from Taiping and Kuala Kangsar by the British. Schebesta in 1924 and Williams-Hunt around 1950 observed Semang making charcoal drawings and they likely continued to make drawings up until the late 1900s if the Gua Dayak peace symbol is an indication.

Today the sites are threatened by vandalism, algal growth and, at Gua Badak, fading brought about by increased exposure to the elements as a result of quarrying in the mid 1980s. This once sacred part of the Semang landscape is now deteriorating rapidly with changes noted even in the short three year time span between fieldwork in 2007 and 2010.

\section{Acknowledgements}

Mohd Rosli Mat Ali, Azman Abdullah, Shaiful Idzwan Shahidan, Noel Hidalgo Tan, Barry Lewis, Alan Thorne and Goh Hsioa Mei are thanked for assistance in the field from November 2007 and June 2010. Shaiful Idzwan Shahidan and Noel Hidalgo Tan are also thanked for assistance with archival research. Hamid Mohd Isa is thanked for information on the contemporary Semang. We are also grateful to the local people of the Lenggong 
Valley. The Universiti Sains Malaysia and Griffith University, Queensland, Australia, are thanked for logistical and financial support. Photographs are by P.S.C. Taçon and the map is by Shaiful Idzwan Shahidan.

\section{References}

ADI, H.T. 1990. Conservation and management problems of rock art sites in peninsular Malaysia. Malaysia in History 18: 92-101.

- 2007. Archaeology of Ulu Kelantan. Kuala Lumpur: Department of Museums Malaysia.

BAHN, P. \& J. VeRTUT. 1997. Journey through the Ice Age. London: Weidenfeld \& Nicolson.

BASTIN, J. \& R.W. WINKS. 1966. Malaysia: selected historical readings. Kuala Lumpur: Oxford University Press.

BELLWOOD, P. 1988. Archaeological research in south-eastern Sabah (Sabah Museum Monograph 2). Kota Kinabalu: Sabah Museum and State Archives.

CHEN, Z. 2001. Asia, in D. Whitley (ed.) Handbook of rock art research: $760-85$. Walnut Creek (CA): Altamira.

CHIA, S. 1997. Prehistoric pottery sources and technology in peninsular Malaysia based on compositional and morphological studies (Malaysia Museums Journal Monograph 33). Kuala Lumpur: Department of Museums and Antiquity Malaysia.

ClodD, H.P. 1948. Malaya's first British pioneer: the life of Francis Light. London: Luzac.

CoCKBURN, J. 1899. Cave drawings in the Kaimur range, Northwest Provinces. Journal of the Straits Branch of the Royal Asiatic Society 32: 89-97.

DALY, D.D. 1879. Caves at Sungei Batu in Selangor. Journal of the Straits Branch of the Royal Asiatic Society 3: 116-19.

DATAN, I. 1993. The charcoal drawings at Gua Sireh. The Sarawak Museum Journal 45(66): 137-61.

- 1998a. Cave drawings, in N.H. Shuhaimi \& N.A. Rahman (ed.) The encyclopedia of Malaysia, Volume 4: early history: 42-43. Singapore: Archipelago Press.

- 1998b. Rock engravings, in N.H. Shuhaimi \& N.A. Rahman (ed.) The encyclopedia of Malaysia, Volume 4: early history: 40-41. Singapore: Archipelago Press.

EVANS, I.H.N. 1918. Preliminary report on cave exploration, near Lenggong, Upper Perak. Journal of the Federated Malay States Museums 7: 227-34.

- 1922a. Further notes on Negrito beliefs. Journal of the Federated Malay States Museums 9: 191-221.

- 1922b. On an examination of Negrito combs from Perak. Journal of the Federated Malay States Museums 9: 223-26.

- 1923. Some beliefs of the Lenggong Negritos. Journal of the Federated Malay States Museums 12: 17-21.
- 1927a. Further notes on Lenggong Negritos. Journal of the Federated Malay State Museums 12: 101-104.

- 1927b. Negrito cave drawings at Lenggong, Upper Perak. Journal of the Federated Malay State Museums 12: 105-106, pls. 28-32.

- 1937. The Negritos of Malaya. London: Frank Cass and Co. Ltd.

Evans, I.H.N. \& P.V.S. CALLENFELS. 1928. Report on cave excavations in Perak. Journal of the Federated Malay States Museums 12: 145-60.

FAULSTICH, P. 1991. From ashes to gravestones: the charcoal drawings of Gua Badak, Malaysia, in C. Pearson \& B.K. Swartz Jr. (ed.) Rock art and posterity: conserving, managing and recording rock art: 24-27. Melbourne: Australian Rock Art Research Association.

FranKE, A.H. 1902. Notes on rock carvings from Lower Ladakh. The Indian Antiquary 31: 398-401.

GANSSER, A. 1990. Cup-stones, prehistoric cult-objects. Memorie Lincee Scienze Fisiche E Naturali 9(1-3): 49-95.

GoH, H.M. \& S. MOKHTAR. 2009.

Paleolithic-Neolithic transition in Gua Kajang, Lenggong Perak, in S. Mokhtar \& A.R. Kamarudin (ed.) Proceedings of the international seminar on sharing our archaeological heritage, Johor Bahru, Malaysia, 11-15 November 2007: 71-78. Johor: Yayasan Warisan Johor.

Hamid, M.I. 2009. Middle Pleistocene (70 000 years ago) stone tools workshop in Kota Tampan,

Lenggong, Perak, Malaysia, in S. Mokhtar \& A.R. Kamarudin (ed.) Proceedings of the international seminar on sharing our archaeological heritage, Johor Bahru, Malaysia, 11-15 November 2007: 97-104. Johor: Yayasan Warisan Johor.

Hill, C., P. Soares, M. Mormina, V. Macaulay, W. Meehan, J. Blackburn, D. Clarke, J. Maripa RAJA, P. ISMAIL, D. BULBECK, S. OPPENHEIMER \& M. Richards. 2006. Phylogeography and ethnogenesis of aboriginal Southeast Asians. Molecular Biology and Evolution 23(12): 2480-91.

KNUTH, E. 1962. The oracle at Tambun: Malay and Thai paintings compared. Malaya in History 8(1): 2-10.

MACGregor, I.A. 1955. Notes on the Portuguese in Malaya. Journal of the Straits Branch of the Royal Anthropological Society 28: 5-41.

MATTHEWS, J.M. 1959. Rock paintings near Ipoh. Malaya in History 52: 22-25. 
- 1960. A note on rock paintings recently discovered near Ipoh, Perak, Federation of Malaya. Man 60: 1-3, pls. A \& B.

May, S.K., P.S.C. Taçon, M. Travers \& D. Guse. 2010. Painting history: indigenous observations and depictions of the 'other' in north-western Arnhem Land, Australia. Australian Archaeology 71: 57-65.

MAXWELL, W.E. 1881. The history of Perak from native sources. Journal of the Straits Branch of the Royal Asiatic Society 9: 258-59.

MOKHTAR, S. 2008. Malaysian prehistoric works of art, in N.A.D. Mohamed (ed.) Susurmasa [Timelines]. Seni Lukis Malaysia Bersama 50 Tahun Balai Seni Lukis Negara [Malaysian art with 50 years of the National Art Gallery]: 32-39. Kuala Lumpur: National Art Gallery Malaysia.

Mokhtar, S., P.S.C. TaÇOn, D. Yang, G. Nash, S.K. MAY \& B. LEWIS. 2008. Illustrating the past: the rock art of Southeast Asia. Current World Archaeology 29: 40-48.

NASIR, A.H. 1977. Sejarah Perak: Pertama. Kuala Lumpur: Jabatan Muzium.

PRICE, L. 2002. Some $19^{\text {th }}$ century visitors to caves in peninsular Malaysia. ACTA Carsologica 31(2): 233-47.

SCHEBESTA, P. 1928. Among the forest dwarfs of Malaya. London: Hutchinson and Co. Ltd.

Skeat, W.W. \& C.O. Blagden. 1906. Pagan races of the Malay Peninsula. London: Frank Cass and Co. Ltd.
TAN, N.H. 2010. Revisiting the rock art of Gua Tambon, Perak, Malaysia. Unpublished MA dissertation, Universiti Sains Malaysia.

TAN, N.H. \& S. CHIA. 2010. 'New' rock art from Gua Tambun, Perak, Malaysia. Rock Art Research 27(1): 9-18.

Williams-HunT, P.D.R. 1951. Recent archaeological discoveries in Malaya (1945-50). Journal of the Malayan Branch of the Royal Asiatic Society 24: 186-91.

- 1952a. An introduction to Malayan Aborigines. Kuala Lumpur: Government Press.

- 1952b. Recent archaeological discoveries in Malaya, 1951. Journal of the Malayan Branch of the Royal Asiatic Society 25: 181-90.

WraY JR., L. 1897. The cave dwellers of Perak. The Journal of the Anthropological Institute of Great Britain and Ireland 26: 36-47.

ZulKifli, J. 2003. Gua-Gua Batu Kapur Di Malaysia: dalam perspektif arkeologi [Ancient limestone landscapes of Malaysia: an archaeological insight]. Kuala Lumpur: Department of Museums and Antiquities.

Zuraina, M. 1994. The excavation of Gua Gunrung Runtuh and the discovery of the Perak Main in Malaysia. Kuala Lumpur: Department of Museums and Antiquity Malaysia.

- 2003. Archaeology in Malaysia. Penang: Centre for Archaeological Research, Universiti Sains Malaysia. 